\title{
Accuracy of Magnetic Resonance Arthrography in Detecting Rotator Cuff Tears
}

\author{
R Bullock ${ }^{1}$, S Shah ${ }^{1}$, T Dundas ${ }^{2}$, A Mansingh ${ }^{1}$, M Frankson ${ }^{3}$, D Soares ${ }^{1}$
}

\begin{abstract}
Objective: Shoulder pain, a common cause of productivity loss and health-related expense, is commonly due to rotator cuff tears. Magnetic resonance (MR) imaging with intra-articular gadolinium, MR arthrography, is accepted internationally as an excellent modality for evaluating the rotator cuff. Ultrasound is cheaper and only slightly less sensitive in detecting rotator cuff tears, but MR is superior in detecting ancillary lesions. Magnetic resonance arthrography was introduced at the University Hospital of the West Indies (UHWI), Jamaica, in July 2003. This study aimed to evaluate our experience with MR arthrography and assess its accuracy. Methods: A retrospective study was carried out. All MR arthrography cases performed at UHWI between July 2003 and July 2006 were reviewed. Medical records were reviewed to determine surgical correlation.

Results: A total of 140 MR arthrograms were performed; 55\% of the patients were female. Ages ranged from the second to the ninth decade, having a distribution approaching but not attaining a normal distribution ( $\mathrm{p}=0.03$ ) with clustering in the middle years. Magnetic resonance arthrography demonstrated torn rotator cuffs in 40 patients, none of whom was under the age of 40 years $(\mathrm{p}<0.001)$. Fifteen patients had surgery which confirmed torn rotator cuffs in all 15.

Conclusion: Magnetic resonance arthrography was found to be accurate in detecting rotator cuff tears. It should be considered in the evaluation of patients with suspected rotator cuff tears. For patients under the age of 40 years, sonography could be used as an alternative.
\end{abstract}

Keywords: Magnetic resonance arthrography, rotator cuff injury, rotator cuff tears in women

\section{Precisión de la artrografía por resonancia magnética en la detección de desgarros del manguito rotador \\ R Bullock ${ }^{1}, S_{\text {Shah }}^{1}$, T Dundas ${ }^{2}$, A Mansingh ${ }^{1}$, M Frankson ${ }^{3}$, D Soares ${ }^{1}$}

\begin{abstract}
RESUMEN
Objetivo: El dolor en el hombro, el cual es causa común de pérdida de productividad y gastos relacionados con la salud, se debe comúnmente a desgarros del manguito rotador. La imagen por resonancia magnética (IRM) con gadolinio intra-articular - conocida como artrografia
\end{abstract}

From: ${ }^{1}$ Section of Radiology, Department of Surgery, Radiology, Anaesthesia and Intensive Care, The University of the West Indies, Mona, and University Hospital of the West Indies, Kingston, Jamaica, West Indies, ${ }^{2}$ Mandeville Regional Hospital, Mandeville, Manchester, Jamaica, West Indies and ${ }^{3}$ The University of the West Indies, School of Clinical Medicine and Research, Research Unit, Nassau, The Bahamas, West Indies.
Correspondence: Dr D Soares, Section of Radiology, Department of Surgery, Radiology, Anaesthesia and Intensive Care, University Hospital of the West Indies, Golding Avenue, Mona, Kingston 7, Jamaica, West Indies. Email: deanne.soares@uwimona.edu.jm 
$R M$ - se acepta internacionalmente como una excelente modalidad para evaluar el manguito rotador. El ultrasonido es más barato y sólo ligeramente menos sensible a la hora de detectar desgarros del manguito rotador, pero la RM es superior en la detección de lesiones secundarias. La artrografía por resonancia magnética se introdujo en el Hospital Universitario de West Indies (HUWI), Jamaica, en julio de 2003. Este estudio tuvo como objetivo evaluar nuestra experiencia con la artrografía RM y evaluar su precisión.

Métodos: Se realizó un estudio retrospectivo. Se revisaron todos los casos de artrografías $R M$ realizadas en HUWI entre julio de 2003 y julio de 2006. Se revisaron las historias clínicas a fin de determinar la correlación quirúrgica.

Resultados: Un total de 140 artogramas RM fueron realizados. El 55\% de los pacientes eran mujeres. Las edades variaron del segundo al noveno decenio, con una distribución que se acercaba pero no llevaba a alcanzar una distribución normal $(\mathrm{p}=0.03)$, concentrándose en los años intermedios. La artrografía de resonancia magnética mostró desgarros de los manguitos rotadores en 40 pacientes, ninguno de los cuales tenía menos de 40 años $(\mathrm{p}<0.001)$. Quince pacientes tuvieron cirugía que confirmaba desgarros de los manguitos rotadores en los 15.

Conclusión: Se halló que la artrografía por resonancia magnética era exacta a la hora de detectar los desagarros del manguito rotador. Debe considerarse en la evaluación de pacientes con sospecha de desgarros del manguito rotador. Para los pacientes menores de 40 años de edad, la sonografía podría ser utilizada como alternativa.

Palabras clave: Artrografía por resonancia magnética, lesión del manguito rotador, desgarros del manguito rotador en mujeres

\section{West Indian Med J 2018; 67 (2): 144}

\section{INTRODUCTION}

Rotator cuff tears are a common cause of shoulder pain and restricted joint motion, especially in the older population $(1,2)$. These symptoms are responsible for both a substantial loss of productivity and healthrelated costs (3). History and physical examination can suggest the diagnosis of a torn rotator cuff with reasonable accuracy (4). Several imaging modalities have been employed to confirm the diagnosis of a cuff tear. These include plain radiographs, computed tomography (CT), arthrography (fluoroscopic or CT) and ultrasound (5).

Plain radiographs are insensitive and, in a number of cases, may be normal, especially in the acute setting. They may show a variety of indirect signs in more advanced or chronic cases of a cuff tear $(6,7)$, but there is some overlap with asymptomatic changes related to the age of the patient (2). They are useful for demonstrating bony changes such as fractures and degenerative disease and may demonstrate findings responsible for rotator cuff impingement. The presence of soft tissue calcification may indicate calcific tendonitis of the rotator cuff. These calcifications have been shown to be associated with cuff tears (8). However, it is impossible to visualize a rotator cuff tear directly using this modality (9).

Computed tomography is better than plain radiography in demonstrating bony details and soft tissue calcifications. Three-dimensional CT can be used to evaluate the subacromial space and causes of impingement (10). Intra-articular contrast at CT (CT arthrography) is useful for demonstrating full thickness tears of the supraspinatus tendon (99\%), but it has lower sensitivities for the subscapularis tendon [64\%] (11).

Sonography is very sensitive and specific for full thickness tears with a sensitivity approaching $100 \%$ in experienced observers $(12,13)$. In many institutions, it is used as the first-line modality in exclusion of the same. However, in some series, it is less sensitive for $80 \%$ partial thickness tears (12). Moosmayer et al demonstrated that 13 of 14 partial thickness tears were not detected at sonography (14). This may reflect the fact that sonography is more observer-dependent and the complexity of the joint further exacerbates the inherent pitalls of sonography, particularly in the hands of the inexperienced (15). Further, Cole et al demonstrated that musculoskeletal sonographers outperformed general sonographers with a sensitivity of $97 \%$ versus $91 \%$ 
and a specificity of $95 \%$ versus $86 \%$, respectively, for the detection of rotator cuff tears (16).

Magnetic resonance (MR) imaging (MRI) with intra-articular gadolinium (MR arthrography) is accepted internationally as a highly reliable tool for evaluating rotator cuff tears. For full-thickness tears, sensitivity, specificity and accuracy were 96\%, 99\% and $98 \%$, respectively, and for partial tears $80 \%, 97 \%$ and $95 \%$, respectively $(17,18)$. It is also the best modality for the detection of ancillary findings such as labral tears $(19,20)$. It has a higher sensitivity for both labral tears and rotator cuff tears than plain MRI (17) and sonography (21).

Computed tomography arthrography performed poorly in a study by Bachmann et al in 1998, demonstrating only $73 \%$ full thickness tears compared with $100 \%$ at MR arthrography (22). However, with the advent of multidetector CT, Oh et al demonstrated comparable detection rates for full thickness tears at CT arthrography compared to MR arthrography. Computed tomography arthrography was found to be less reliable for partial thickness tears (23).

In 2002, we began performing plain (nonarthrographic) MRI at the University Hospital of the West Indies (UHWI), Jamaica, on patients with a history suggestive of rotator cuff injury. Magnetic resonance arthrography was introduced at UHWI in July 2003 with a view to improving the detection rate. The purpose of this study was to evaluate our experience with MR arthrography and to assess its accuracy.

\section{SUBJECTS AND METHODS}

A retrospective study was carried out for the period July 2003 to July 2006. We reviewed all cases of MRI followed with MR arthrography, performed in patients with suspected rotator cuff tears. Patients who had MRI alone were not included in the study.

All patients were imaged using the 1.5 Tesla Signa Smartspeed MR unit (GE Medical Systems, Milwaukee, United States of America) before contrast injection into the joint. The imaging sequences employed included Sagittal PD fs FSE, Coronal PD fs FSE, T2, and Axial T2*, T1.

After the plain MRI was done, the patient would have been transferred to the fluoroscopic unit (GE Legacy Advantx DRS) and arthrography performed under fluoroscopic guidance. A combination of 0.1 $\mathrm{ml}$ of meglumine gadopentate (Magnevist $\mathrm{t}^{\mathbb{B}}$, Bayer Schering Pharma AG, Germany) together with
Ultravist ${ }^{\circledR} 300$ (Bayer Schering) and sterile water was instilled into the shoulder joint. Ultravist, radiographic contrast, was used to facilitate visibility during fluoroscopy. Following arthrography, fat-suppressed T1 weighted images were performed in all three planes. The plain MR and MR arthrogram for each patient were reviewed separately.

For each MR case, the rotator cuff was evaluated for tears or tendinosis. If a tear was detected, its site and thickness were recorded. Age and gender distribution were analysed to determine if these variables were statistically significant in the occurrence of rotator cuff tears. Other anatomical sites (long head of biceps tendon, acromion and acromioclavicular (AC) joint, subacromial space and labra) were evaluated and ancillary findings documented. Medical records were reviewed to determine surgical correlation. Data were analysed using SPSS.

This study received approval of The University Hospital of the West Indies Ethics Committee.

\section{RESULTS}

A total of 140 studies (plain MRI followed by MR arthrography for each patient) were performed over the three-year period. There were 77 female and 63 male patients. Ages ranged from 16 to 82 years. Rotator cuff tears were the most common pathology. Plain MRI detected 35 tears. Magnetic resonance arthrography detected an additional five tears. In total, rotator cuff tears were seen in 40 patients ( $29 \%$ of MR arthrograms). Of these 40 tears, 38 (95\%) involved the supraspinatus tendon. Two tears were of the subscapularis tendon $(5 \%)$. No tears involved the infraspinatus or teres minor tendons. Independent of site, 30 were full thickness tears $(75 \%)$ and 10 were partial thickness tears $(25 \%)$. The most common location for supraspinatus tears was at its insertion (36 cases, 95\%).

Other abnormalities detected in the MR arthrography series were as follows in descending order of frequency: tendinosis $(10 \%)$, subacromial impingement $(9 \%)$, AC joint degeneration (7\%), labral tears $(6 \%)$, greater tuberosity fracture $(1 \%)$. No abnormalities of the long head of the biceps tendon were noted. With respect to the eight labral tears seen at MR arthrography, only four (50\%) were appreciated on plain MRI. Fifty-five per cent of the MR studies were in women. Cuff tears on MR arthrography showed a 11:9 distribution of female:male patients. This distribution of cuff tears paralled exactly the gender distribution of all the patients. 
No rotator cuff tears were seen in patients below 40 years of age (Figure). This group comprised 48 of the 140 patients. Of these 48 patients, 14 had tendinosis $(29 \%), 3$ had fractures $(6 \%), 3$ had degenerative change $(6 \%)$ and the remainder were normal $(59 \%)$. The distribution of the age of patients diagnosed with rotator cuff tears was clustered to the years of midlife, tapering with increasing years (Figure). If all age ranges were considered, the distribution was not normal $(p<0.001)$, being skewed to the left. In the 15 patients who underwent surgical exploration, all patients had rotator cuff tears, consistent with their previous findings at MRA. (Of note, the five patients who had undiagnosed tears at MRI, which were later detected at MRA, were a part of the group undergoing surgical exploration.) The remaining 25 patients were managed without surgical intervention.

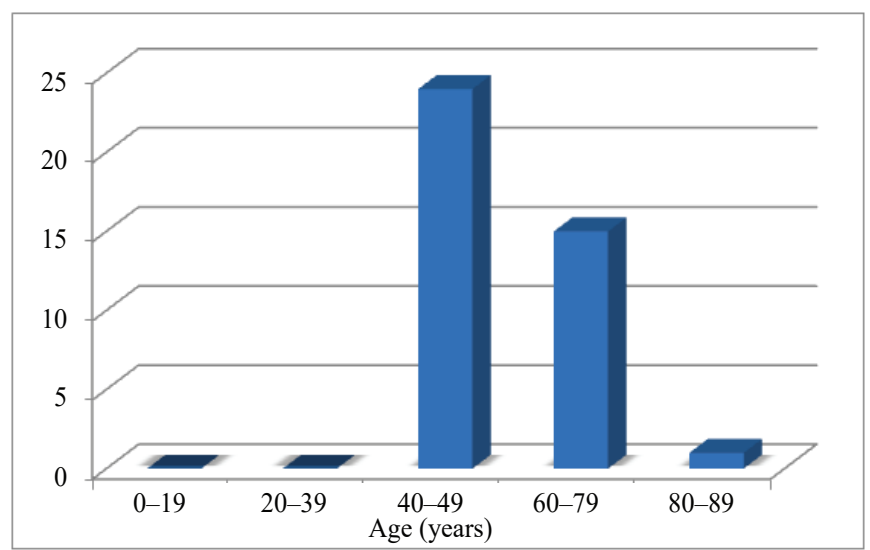

Figure: Number of rotator cuff tears categorized by age groups.

\section{DISCUSSION}

Our series showed MR arthrography to be a reliable tool with a sensitivity of $100 \%$, and plain MRI demonstrated a sensivity of $67 \%$ for surgically confirmed tears. The five patients who had undetected tears with plain MRI had their tears detected with MR arthrography and subsequently confirmed at surgery. Appropriate management of these patients was facilitated by the inclusion of MRA in their investigations. We also detected more partial tears and labral tears at MR arthrography than with plain MRI. However, as surgery was not clinically indicated in all cases, definitive confirmation was not possible.

The most common site of tears at the insertion of the supraspinatus tendon followed recognized international trends and related to relative avascularity of this zone (24). The age distribution of tears related well to trends in other populations. The distribution of cuff tears was also noted to parallel exactly the gender distribution of the patients in this study, ie there were more women than men. No patient under the age of 40 years was found to have a tear. Tendinosis was the most common demonstrable pathology in this age group.

Plain radiographs are inexpensive, having limited utility in patients with shoulder pain. However, they can be useful in excluding fractures and dislocations in acute trauma, detecting calcific tendinosis, degenerative changes, and bony factors leading to cuff impingement.

Sonography is reliable for exclusion of full thickness tears and can detect features of tendinosis. Therefore, it is proposed that for patients under the age of 40 years of age, sonography plus or minus plain radiography could be chosen as a cheaper, non-invasive alternative, given the lack of tears found in this group and the occurrence of a few fractures and degenerative disease. To date, sonography is not reliable in detection of ancillary findings such as labral tears. Therefore, for patients with persistent shoulder pain with a normal sonogram, MR arthrography is indicated.

Fluoroscopic arthrography will continue to have a role in evaluating patients with suspected cuff/labral tears who cannot undergo MR arthrography for whatever reason (eg claustrophobia, pacemaker) and also in settings where neither CT nor MRI is available. If CT is available, CT arthrography is superior to fluoroscopic arthrography and very useful for the demonstration of associated bony pathology and lesions of the surface of the articular cartilage (25).

\section{CONCLUSION}

Magnetic resonance arthrography is invasive and expensive, a major consideration in our setting. However, due to its superior sensitivity and specificity for both cuff tears and ancillary lesions, MR arthrography should be considered in the evaluation of patients in whom there is a high index of suspicion for rotator cuff tears, whenever possible.

\section{REFERENCES}

1. Fuchs S, Chylarecki C, Langenbrinck A. Incidence and symptoms of clinically manifest rotator cuff lesions. Int J Sports Med 1999; 20: 201-5.

2. Bonsell S, Pearsall AW $4^{\text {th }}$, Heitman RJ, Helms CA, Major NM, Speer KP. The relationship of age, gender, and degenerative changes observed on radiographs of the shoulder in asymptomatic individuals. $\mathrm{J}$ Bone Joint Surg Br 2000; 82: 1135-9.

3. Feuerstein M, Miller VL, Burrell LM, Berger R. Occupational upper extremity disorders in the federal workforce. Prevalence, health care expenditures, and patterns of work disability. J Occup Environ Med 1998; 40: 546-55.

4. Litaker D, Pioro M, El Bilbeisi H, Brems J. Returning to the bedside: using the history and physical examination to identify rotator cuff tears. J Am Geriatr Soc 2000; 48: 1633-7. 
5. Loustau O, Sans N, Despeyroux-Ewers ML, Chiavassa-Gandois H, Vial J, Railhac JJ. Shoulder pain: image guided management. J Radiol 2007; 88: $1238-41$.

6. Pearsall AW $4^{\text {th }}$, Bonsell S, Heitman RJ, Helms CA, Osbahr D, Speer KP. Radiographic findings associated with symptomatic rotator cuff tears. J Shoulder Elbow Surg 2003; 12: 122-7.

7. Hamada K, Fukuda H, Mikasa M, Kobayashi Y. Roentgenographic findings in massive rotator cuff tears. A long-term observation. Clin Orthop Relat Res 1990; 254: 92-6.

8. Jim YF, Hsu HC, Chang CY, Wu JJ, Chang T. Coexistence of calcific tendinitis and rotator cuff tear: an arthrographic study. Skeletal Radiol 1993; 22: 183-5.

9. Moosikasuwan JB, Miller TT, Burke BJ. Rotator cuff tears: clinical, radiographic, and US findings. Radiographics 2005; 25: 1591-607.

10. Lochmuller EM, Maier U, Anetzberger H, Habermeyer P, Muller-Gerbl M. Determination of subacromial space width and inferior acromial mineralization by 3D CT. Preliminary data from patients with unilateral supraspinatus outlet syndrome. Surg Radiol Anat 1997; 19: 329-37.

11. Charousset C, Bellaiche L, Duranthon LD, Grimberg J. Accuracy of CT arthrography in the assessment of tears of the rotator cuff. J Bone Joint Surg Br 2005; 87: 824-8.

12. Milosavljevic J, Elvin A, Rahme H. Ultrasonography of the rotator cuff: a comparison with arthroscopy in one-hundred-and-ninety consecutive cases. Acta Radiol 2005; 46: 858-65.

13. Teefey SA, Rubin DA, Middleton WD, Hildebolt CF, Leibold RA, Yamaguchi K. Detection and quantification of rotator cuff tears: comparison of ultrasonographic, magnetic resonance imaging, and arthroscopic findings in seventy-one consecutive cases. J Bone Joint Surg Am 2004; 86-A: 708-16

14. Moosmayer S, Heir S, Smith HJ. Sonography of the rotator cuff in painful shoulders performed without knowledge of clinical information: results from 58 sonographic examinations with surgical correlation. J Clin Ultrasound 2007; 35: 20-6.

15. Rutten MJ, Jager GJ, Blickman JG. From the RSNA refresher courses: US of the rotator cuff: pitfalls, limitations, and artifacts. RadioGraphics 2006; 26: 589-604.
16. Cole B, Twibill K, Lam P, Hackett L, Murrell GA. Not all ultrasounds are created equal: general sonography versus musculoskeletal sonography in the detection of rotator cuff tears. Shoulder Elbow 2016; 8: $250-7$.

17. Magee T, Williams D, Mani N. Shoulder MR arthrography: which patient group benefits most? AJR Am J Roentgenol 2004; 183: 969-74.

18. Waldt S, Bruegel M, Mueller D, Holzapfel K, Imhoff AB, Rummeny EJ et al. Rotator cuff tears: assessment with MR arthrography in 275 patients with arthroscopic correlation. Eur Radiol 2007; 17: 491-8.

19. Robinson G, Ho Y, Finlay K, Friedman L, Harish S. Normal anatomy and common labral lesions at MR arthrography of the shoulder. Clin Radiol 2006; 61: 805-21.

20. Applegate GR, Hewitt M, Snyder SJ, Watson E, Kwak S, Resnick D. Chronic labral tears: value of magnetic resonance arthrography in evaluating the glenoid labrum and labral-bicipital complex. Arthroscopy 2004; 20: 959-63.

21. Ferrari FS, Governi S, Burresi F, Vigni F, Stefani P. Supraspinatus tendon tears: comparison of US and MR arthrography with surgical correlation. Eur Radiol 2002; 12: 1211-7.

22. Bachmann G, Bauer T, Jürgensen I, Schwab J, Weimar B, Rau WS. The diagnostic accuracy and therapeutic relevance of $\mathrm{CT}$ arthrography and MR arthrography of the shoulder. Rofo 1998; 168: 149-56.

23. Oh JH, Kim JY, Choi JA, Kim WS. Effectiveness of multidetector computed tomography arthrography for the diagnosis of shoulder pathology: comparison with magnetic resonance imaging with arthroscopic correlation. J Shoulder Elbow Surg 2010; 19: 14-20.

24. Kim SY, Boynton EL, Ravichandiran K, Fung LY, Bleakney R, Agur AM. Three-dimensional study of the musculotendinous architecture of supraspinatus and its functional correlations. Clin Anat 2007; 20: $648-55$.

25. Jarraya M, Roemer FW, Gale HI, Landreau P, D'Hooghe P, Guermazi A. MR-arthrography and CT-arthrography in sports-related glenolabral injuries: a matched descriptive illustration. Insights Imaging 2016; 7: $167-77$. 